\title{
How Important is the Integration of Public Passenger Transport
}

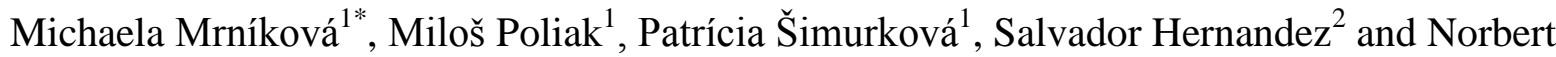 \\ Reuter $^{3}$
}

${ }^{1}$ University of Zilina, Faculty of Operation and Economics of Transport and Communication, Department of Road and Urban Transport, Univerzitná 1, 01026 Zilina, Slovak Republic; Email: michaela.mrnikova@pedas.uniza.sk, milos.poliak@fpedas.uniza.sk, patricia.simurkova@pedas.uniza.sk

${ }^{2}$ School of Civil and Construction Engineering, Oregon State University, Corvallis, Oregon, USA; Email: sal.hernandez@oregonstate.edu

${ }^{3}$ Managing Director of Saarbahn GmbH, Saarbrücken, Germany; Email: norbert.reuter@web.de

\section{*Corresponding Author: Michaela Mrníková}

\begin{abstract}
The significance of the issue of an effective mode of passenger transport is currently increasing. On the one hand, there is the increasing economic demand of public passenger transport, on the other hand, there is the growing traffic share of individual automobile transport. The objective of the paper is to analyze public passenger transport without mutual integration of individual transport systems resulting in the fact that it is not sufficiently able to compete with individual automobile transport. It is proposed the integration of different modes of public passenger transport as a way to increase the competitiveness of public passenger transport. Aim of this paper is to analyze the individual elements of integration systems and describe why integration of public passenger transport systems is needed.
\end{abstract}

Keywords: Integration, public passenger transport, political phase, strategic phase, realization phase

\section{Introduction}

System of public passenger transport is important, because the current traffic system faces well known problems like congestion, environmental impact and use of public space. Non-integrated public transport systems tend to neglect the needs of customers, which ultimately results in a decrease of ridership. In particular, the absence of an integrated public passenger transport system causes the problems and inconveniences for customers and authorities for example travel time (where connection and timetables between public transport operators are not harmonized), comfort (for a single-trip ride is needed more than one ticket), costs (in some traffic relations exist parallel and competitive services) and information (the passenger faces a non-transparent system of tariffs).

EU transport strategy prefers the transport of passengers by public passenger transport to the individual transport because the use of public passenger transport results in gradually meeting all the 
goals of the EU strategy in sector of public transport (for example: In the field of road safety what it relates mainly to the stabilization of the increased road transport claims on infrastructure whose expansion is problematic especially in built-up areas; The reduction of the EU's dependence on crude oil as a raw material that needs to be imported into the EU. It means the support of public passenger transport brings lower fuel consumption. Based on the above considerations it has been concluded that the strategic objectives of the EU transport policy are achieved when population uses the public passenger transport. In this regard it has to be noted that it is necessary to support the public passenger transport and its competitiveness in relation to the individual automobile transport [1]. The aim of this paper is to identify the importance of public passenger transport and to define the effective method of creating the integrated transport systems.

Generally speaking, many definitions of public passenger transport integration can be found in literature [2-6] but the most popular are those formulated [7] as Integration is the organizational process, in which the elements of public transport system (network and infrastructure, fares and tickets, information and marketing, etc.) served by various operators, who use different modes of transport, interact more efficiently and closely. This results in general improvement in travel conditions and quality of service; or Integration is the way in which the individual elements of public transport are embedded in the chain of movement.

Public transport is to provide an attractive chain of services in the "door to door" relationship [7], making integration as a combination of different means of public transport, public and individual transport and transport policy with regard to spatial planning or investment in infrastructure.

In practice, it is necessary to apply a more strategic form of integration that is directly relevant to strategy formulation: the integration of individual policy instruments achieves greater performance from the overall strategy [8]. This integration can occur in four general ways:

(1) Integration between policy instruments involving different types of these instruments.

(2) Integration between policy instruments including the use of infrastructure, management, information and price.

(3) Integration between transport measures and land use planning measures.

(4) Integration with other policy areas such as health and education.

It is crucial to create some interconnection between integrations to establish an optimal setting for transport serviceability system. Integration of types (1) - (3) draws on the wide range of different types of transport and land use policy instrument currently available. In addition, it is necessary to point out that the combination of policy instruments is likely to perform differently against a given objective from applying the individual instruments alone. 
Dealing with the transport integration, it is inevitable to define basic features such as: number of journeys, lines, and the share of transport modes and daily system operation. Some instruments will also change the supply of transport, and thus the costs to users. The costs of implementation and operation and revenues generated will also have an impact on instruments, alone and in combination. Each of them will affect the scale and intensity that is used as a policy instrument; fare changes, for example, can vary in magnitude by time of day and potentially by route and area. The number of possible policy combinations is very extensive. A carefully designed integrated strategy, particularly of types (1) - (3) should be able to achieve the objectives set for one or more adopted policy instruments. Some of the integrations outlined above may prompt a wider set of objectives; for example integration of transport and land (type 3) can well raise the set of development objectives [9]. With any strategy, it is important to clarify the objectives before the strategy is developed, because the combination of suitable policy instruments, for example for the pursuit of economic development will differ from those which best meet environmental and health targets.

\section{Data}

The introduction of an integrated transport system contributes to the attractiveness of public transport (PT). This contributes to reducing the number of passenger cars. Performance in public passenger transport can be reduced if the systems are not integrated. This situation is called a „vicious circle” (Fig. 1).

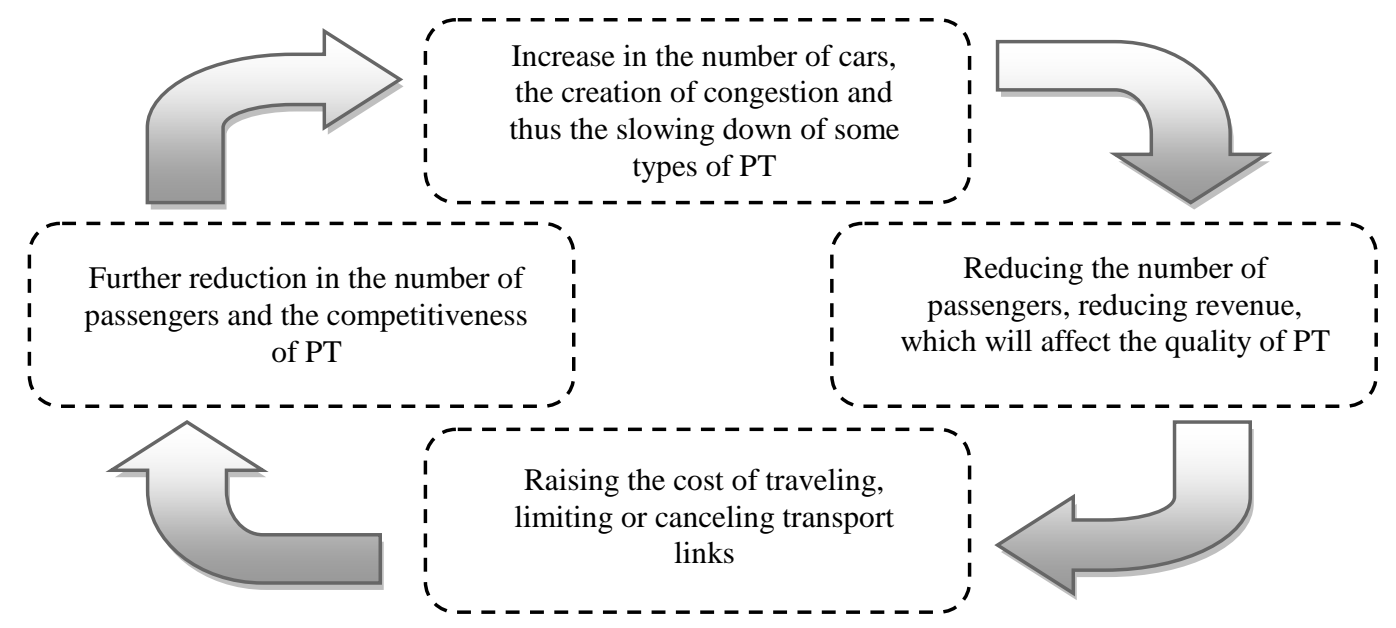

Fig. 1 The vicious circle of public transport. Source: [10,11]

This situation (before and after integration) was analyzed based on data from the statistics of the Slovak Republic, European statistics from Eurostat and Directorate-General for Mobility and Transport of the EU. The data include information on the performance by mode for public passenger transport in millions of passenger-kilometers (mil. pkm) and modal split of public passenger transport modes in percent (\% of total mil. pkm) for the period 1995 to 2015 . Data has been split by 
mode of transport to individual car transport, road transport (bus and urban transport) and rail transport in European Union countries (EU-28). Of all the European countries were selected four countries with a functioning integrated transport system (Czech Republic, Germany, Austria and Switzerland) and four countries with partially functioning integrated system or without introducing integration (Slovak Republic, Romania, Bulgaria and Albania).

The study was analyzed as the impact of the introduction of an integrated transport system to increase the attractiveness of public transport in countries with partially integration or without integration. In this paper, the definition of the effective method of creating the integrated transport systems is outlined.

\subsection{Transport Performance in Public Passenger Transport}

The study analyzed transport performance of public passenger transport and focused on the relationship between individual transport, bus and urban transport and rail transport (Fig.2). The development of these performances has been investigated over a twenty-year period (1995 - 2015).

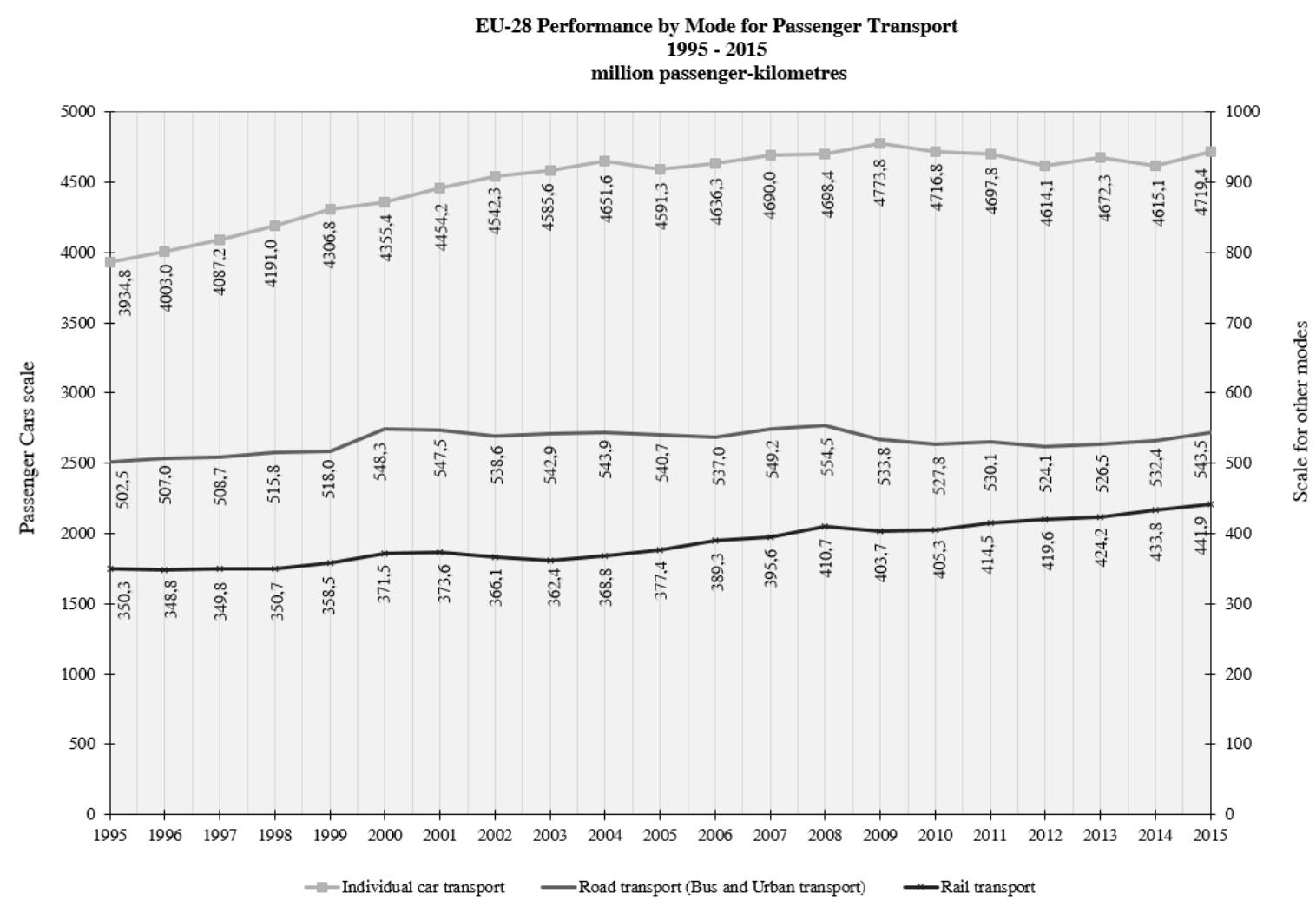

Fig. 2 Performance by mode for public passenger transport in millions of passenger-kilometers (EU28) for the period 1995 to 2015. Source: authors

The highest increase in passengers occurs in individual transport (Fig. 2). For comparison, since 1995, individual transport performance has increased from 3,924.8 mil. pkm to 4719.4 mil. pkm in 2015. Bus and urban transport and rail transport did not notice a significant increase. 
Table 1 Performance by mode for public passenger transport in millions of passenger-kilometers (EU-28) for the period 1995 to 2015. Source: [12]

\begin{tabular}{|c|c|c|c|c|c|c|c|c|c|c|c|c|c|c|c|c|c|c|c|c|c|}
\hline & 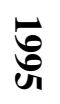 & है: & : & : & 8 & $\tilde{\sigma}$ & 气ิ & 芯 & હ્ّ & 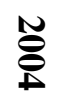 & 菖 & ฮั & 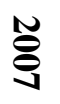 & 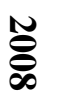 & ฮิ & 苍 & 苂 & $\stackrel{\widetilde{O}}{N}$ & $\stackrel{\tilde{\omega}}{\omega}$ & $\stackrel{\widetilde{E}}{\mathbb{E}}$ & 苍 \\
\hline $\begin{array}{l}\text { Individual } \\
\text { car } \\
\text { transport }\end{array}$ & $\begin{array}{l}\underset{\mathscr{W}}{w} \\
\underset{\phi}{\infty}\end{array}$ & $\begin{array}{l}0 \\
8 \\
. \\
0 \\
0\end{array}$ & $\begin{array}{l}0 \\
0 \\
\infty \\
\text { i } \\
\text { i }\end{array}$ & $\frac{\vec{\theta}}{6}$ & 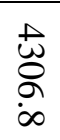 & $\begin{array}{l}\dot{n} \\
\ddot{u} \\
\ddot{n} \\
\dot{\phi}\end{array}$ & 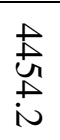 & $\begin{array}{l}E \\
\stackrel{\Delta}{ \pm} \\
i \\
\omega\end{array}$ & $\begin{array}{l}0 \\
0 \\
\infty \\
\qquad \\
a\end{array}$ & $\begin{array}{l}\frac{a}{a} \\
\stackrel{a}{a}\end{array}$ & 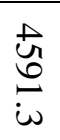 & $\begin{array}{l}\vec{a} \\
\stackrel{\alpha}{\alpha} \\
\dot{\omega}\end{array}$ & $\begin{array}{l}\text { aे } \\
\text { bे } \\
0 \\
0\end{array}$ & $\begin{array}{l}+5 \\
\text { a } \\
\infty \\
+ \\
+\end{array}$ & $\underset{\infty}{ \pm}$ & $\underset{\infty}{\stackrel{D}{\supset}}$ & 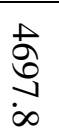 & $\frac{\vec{a}}{\stackrel{\vec{\phi}}{+}}$ & 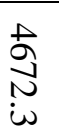 & $\begin{array}{l}\vec{a} \\
\stackrel{\vec{\sigma}}{u} \\
r\end{array}$ & $\underset{๋}{ \pm}$ \\
\hline $\begin{array}{l}\text { Road } \\
\text { transport } \\
\text { (Bus and } \\
\text { Urban } \\
\text { transport) }\end{array}$ & $\begin{array}{l}\text { Ù } \\
\text { N } \\
\text { un }\end{array}$ & 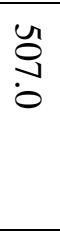 & $\begin{array}{l}\text { Uू } \\
\infty \\
\dot{v}\end{array}$ & $\begin{array}{l}u \\
\ddot{n}\end{array}$ & $\begin{array}{l}u \\
\infty \\
0\end{array}$ & 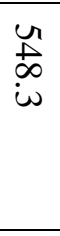 & $\begin{array}{l}u \\
\pm \\
u\end{array}$ & $\begin{array}{l}u \\
\infty \\
\infty \\
a\end{array}$ & 岇 & 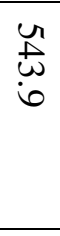 & $\stackrel{u}{ \pm}$ & $\underset{\dot{\omega}}{\tilde{\omega}}$ & $\begin{array}{l}\text { Un } \\
\text { to } \\
\text { is }\end{array}$ & 亗 & $\underset{\omega}{\stackrel{u}{\omega}}$ & $\begin{array}{l}\text { N } \\
\text { D } \\
\infty\end{array}$ & $\stackrel{u}{\mathscr{O}}$ & $\begin{array}{l}\text { N } \\
\stackrel{ \pm}{ \pm}\end{array}$ & 岕 & 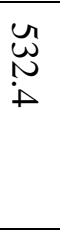 & $\begin{array}{l}n \\
\dot{w} \\
\text { in }\end{array}$ \\
\hline $\begin{array}{l}\text { Rail } \\
\text { transport }\end{array}$ & $\ddot{\omega}_{i}^{w}$ & $\begin{array}{l}\omega \\
+\infty \\
\infty \\
\infty\end{array}$ & $\begin{array}{l}\omega \\
+ \\
\infty \\
\infty\end{array}$ & $\stackrel{w}{\breve{y}}$ & $\begin{array}{l}w_{u} \\
\infty \\
i\end{array}$ & $\underset{\text { ü }}{u_{1}}$ & $\underset{\omega}{\omega}$ & مू & 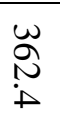 & $\begin{array}{l}\omega \\
\infty \\
\infty\end{array}$ & 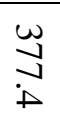 & $\begin{array}{l}w \\
\infty \\
\infty \\
\dot{\omega}\end{array}$ & $\begin{array}{l}w \\
\text { oñ } \\
a\end{array}$ & $\stackrel{\bullet}{0}$ & $\underset{\omega}{0}$ & 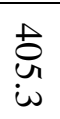 & $\underset{⿱ 亠 䒑}{\stackrel{\oplus}{*}}$ & $\begin{array}{l} \pm \\
\vdots \\
a\end{array}$ & $\begin{array}{l}\stackrel{A}{N} \\
\stackrel{N}{N}\end{array}$ & $\underset{\infty}{\omega}$ & $\frac{+}{ \pm}$ \\
\hline Total & 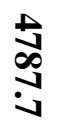 & $\begin{array}{l}\infty \\
\infty \\
\infty \\
\infty \\
\infty\end{array}$ & 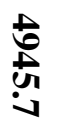 & 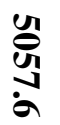 & $\stackrel{\infty}{\infty}_{\omega}^{\omega}$ & 矛 & 嵌 & $\begin{array}{l}\text { Un } \\
\stackrel{+}{ \pm} \\
0\end{array}$ & 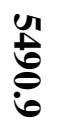 & Uू & 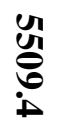 & 湈 & 岁 & שू. & $\underbrace{U}_{i}$ & 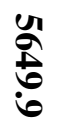 & 袋 & 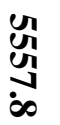 & 岕 & 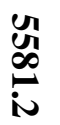 & $\underset{\oplus}{\stackrel{y}{\phi}}$ \\
\hline
\end{tabular}

The study mentions to the ever increasing grown in performance in individual transport. The performance of public transport systems is not as high as performance of individual transport. For example in 2015 performance of individual transport signify 4719.4 mil. pkm for bus and urban transport just 543.5 mil. km and for rail transport 441.9 mil. pkm (Table 1).

\subsection{Modal Split in Public Passenger Transport}

This indicator is defined as the percentage share of each mode of transport in total inland transport, based on the transport performance expressed in passenger-kilometers (pkm). Total inland transport includes transport by passenger cars, buses and coaches, and trains. All data should be based on transport performance on the national territory, regardless of the nationality of the vehicle.

The indicator aims at monitoring the dependence of passenger transport on each individual mode. The indicator is expressed as the percentage of passenger transport by car, buses and coaches, and trains in total inland passenger transport (in passenger-kilometers) in period 1995 to 2015 (Table 2).

Passenger cars accounted for $82.7 \%$ of inland passenger transport in the EU-28 in 2015, with motor coaches, buses and trolley buses $(9.5 \%)$ and trains $(7.7 \%)$ both accounting for less than a tenth of all traffic.

Table 2 Modal split of public passenger transport modes in percent of total mil. pkm (EU-28) for the period 1995 to 2013. Source: [12] 


\begin{tabular}{llcc} 
& & and Urban transport & transport \\
\hline $\mathbf{1 9 9 5}$ & 82.2 & 10.5 & 7.3 \\
\hline $\mathbf{1 9 9 6}$ & 82.4 & 10.4 & 7.2 \\
\hline $\mathbf{1 9 9 7}$ & 82.6 & 10.3 & 7.1 \\
\hline $\mathbf{1 9 9 8}$ & 82.9 & 10.2 & 6.9 \\
\hline $\mathbf{1 9 9 9}$ & 83.1 & 10.0 & 6.9 \\
\hline $\mathbf{2 0 0 0}$ & 82.6 & 10.4 & 7.0 \\
\hline $\mathbf{2 0 0 1}$ & 82.9 & 10.2 & 7.0 \\
\hline $\mathbf{2 0 0 2}$ & 83.4 & 9.9 & 6.7 \\
\hline $\mathbf{2 0 0 3}$ & 83.5 & 9.9 & 6.6 \\
\hline $\mathbf{2 0 0 4}$ & 83.6 & 9.8 & 6.6 \\
\hline $\mathbf{2 0 0 5}$ & 83.3 & 9.8 & 6.8 \\
\hline $\mathbf{2 0 0 6}$ & 83.3 & 9.7 & 7.0 \\
\hline $\mathbf{2 0 0 7}$ & 83.2 & 9.7 & 7.0 \\
\hline $\mathbf{2 0 0 8}$ & 83.0 & 9.8 & 7.3 \\
\hline $\mathbf{2 0 0 9}$ & 83.6 & 9.3 & 7.1 \\
\hline $\mathbf{2 0 1 0}$ & 83.5 & 9.3 & 7.2 \\
\hline $\mathbf{2 0 1 1}$ & 83.3 & 9.4 & 7.3 \\
\hline $\mathbf{2 0 1 2}$ & 83.0 & 9.4 & 7.5 \\
\hline $\mathbf{2 0 1 3}$ & 83.1 & 9.4 & 7.5 \\
\hline $\mathbf{2 0 1 4}$ & 82.7 & 9.5 & 7.8 \\
\hline $\mathbf{2 0 1 5}$ & 82.7 & 9.5 & 7.7 \\
\hline
\end{tabular}

Between 2005 and 2015, the relative importance of the use of passenger cars was quite stable, with its share always within the range of $83.0 \%$ to $83.6 \%$.

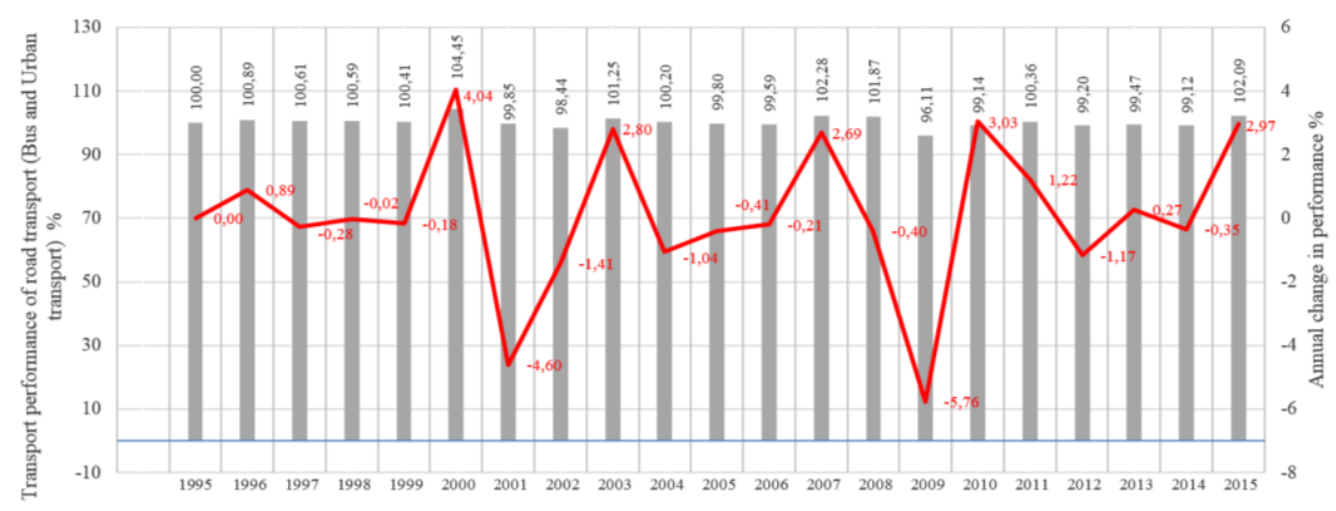

Fig. 3 The development of transport performance in EU-28 in mil. pkm (Bus and Urban Transport) for the period 1995 to 2015 in \%. Source: authors

Combined with this development was a fall in the importance of passenger transport by, buses and trolley buses, down from $4.04 \%$ in 2000 to $-4.6 \%$ by 2001 and down from $2.69 \%$ in 2009 to 5.76 by 2009 (Fig. 3).

\section{Result}

Generally, the share of individual transport performance is steadily increasing in all countries. The average transportation performances for bus service in both cases in countries with integrated 
transport system (Table 3) and countries without integrated transport system (Table 4) take positive values. Difference is to be seen in rail passenger transport in countries without integrated transport system where significant loss of performance by an average of $5 \%$ for the entire period.

Table 3 The development of transport performance in countries with a functioning integrated transport system for period 1995 to 2015 in \%. Source: authors

\begin{tabular}{lcccc}
\hline & $\begin{array}{c}\text { Individual } \\
\text { transport (Cars) }\end{array}$ & $\begin{array}{c}\text { Road Transport } \\
\text { (Bus and Urban } \\
\text { Transport) }\end{array}$ & $\begin{array}{c}\text { Rail transport } \\
\text { (Metro and } \\
\text { Trams) }\end{array}$ & $\begin{array}{c}\text { Rail } \\
\text { transport } \\
\text { (Trains) }\end{array}$ \\
\hline Czech Republic & $1.47 \%$ & $1.58 \%$ & $1.75 \%$ & $-2.71 \%$ \\
\hline Germany & $3.66 \%$ & $-0.18 \%$ & $0.67 \%$ & $1.78 \%$ \\
\hline Austria & $3.66 \%$ & $0.31 \%$ & $5.77 \%$ & $3.38 \%$ \\
\hline Switzerland & $3.41 \%$ & $5.38 \%$ & $-0.90 \%$ & $3.79 \%$ \\
\hline Average performance \% & $\mathbf{3 . 0 5 \%}$ & $\mathbf{1 . 7 7 \%}$ & $\mathbf{1 . 8 2 \%}$ & $\mathbf{1 . 5 6 \%}$ \\
\hline
\end{tabular}

For both tables (Table 3 and Table 4), it should be noted that the investigated values, respectively, positive and negative perceived differences are mainly influenced by the mobility of transport systems in selected countries, where a very big difference is between the countries of Western and Eastern Europe.

Table 4 The development of transport performance in countries without a functioning integrated transport system or with partial integration for period 1995 to 2015 in \%. Source: authors

\begin{tabular}{lcccc}
\hline & $\begin{array}{c}\text { Individual } \\
\text { transport (Cars) }\end{array}$ & $\begin{array}{c}\text { Road Transport } \\
\text { (Bus and Urban } \\
\text { Transport) }\end{array}$ & $\begin{array}{c}\text { Rail transport } \\
\text { (Metro and } \\
\text { Trams) }\end{array}$ & $\begin{array}{c}\text { Rail } \\
\text { transport } \\
\text { (Trains) }\end{array}$ \\
\hline Slovak Republic & $2.25 \%$ & $-5.06 \%$ & $-1.79 \%$ & $-4.41 \%$ \\
\hline Romania & $3.97 \%$ & $6.34 \%$ & $1.93 \%$ & $-5.27 \%$ \\
\hline Bulgaria & $4.13 \%$ & $0.84 \%$ & $4.81 \%$ & $-4.96 \%$ \\
\hline Albania & $6.36 \%$ & $12.81 \%$ & $\mathrm{n}$ & $-5.36 \%$ \\
\hline Average performance \% & $\mathbf{4 . 1 8 \%}$ & $\mathbf{3 . 7 3 \%}$ & $\mathbf{1 . 6 5 \%}$ & $\mathbf{- 5 . 0 0 \%}$ \\
\hline
\end{tabular}

\section{Discussion}

After the performance analysis it is possible to create a proposal of procedure for implementation of the integrated transport system. In the first stage of proposed procedure, it is important to focus on data collection in a specified area where the integrated transport system is to be implemented. Furthermore, it is necessary to identify the common transport systems in that area. The main objective of collecting data is to gather some knowledge about supply and demand in the area concerned [13], having regard to the identification of public transport fleet and its capacity, identification of line routes, number of passengers transferred and identification of transport and transfer services. 
Another important aspect is to record operating speed of vehicles that relates to fuel consumption and emissions. These two aspects can be considered as the potential benefits of the proposed integrated transport systems, as opposed to the transport systems operating at present. After defining all parameters, it is necessary to create a data collection model used for the identification of the most important areas of public transport in the region and then it is required to include these areas into integration.

Data collection is realized during morning and afternoon peak hours. However, data gathered during the off-peak period are also important because it can result in different conditions of public transport operation during the day. Furthermore, it is necessary to admit that data acquired on Monday and Friday are modified because the flow of passengers is not regular in these days (e.g. commuting to other cities at the beginning and end of the week).

The second stage of procedure deals with the analysis of gathered data in order to emphasize the level of travel services for passengers using different travel routes. It is possible to speak of 'an extreme' (e.g. congestion) on travel routes and lines. Consequently, it is important to identify these extremes and suggest ways to avoid them. The outcome of second stage is to determine the total supply and demand for specific lines. To summarize the capacity of all vehicles within the transport system, it is possible to identify this capacity as a supply and the number of all travelers within the system as a demand. To confirm that, the traffic survey is needed.

Based on the current state of the system it is possible to propose various alternatives for implementing the integrated transport system in the third stage. The alternatives are seen as hypothetical phases of a predetermined system which cannot be implemented at the same time [14]. Alternatives are developed under the influence of certain variables that are characterized as the behavior of all components. These alternatives should include the proposed travel routes, vehicles capacity, terminals and stops for passengers, the best combination between different modes of transport or vehicles, from the passenger's point of view as well as the operator's view.

The fourth stage of the procedure deals with the analysis of current alternative with the suggested alternative. This stage is the basis of calculating the benefits of integrated transport system, taking into account already existing system. The system is considered to be effective if it meets all requirements in terms of public transport users, i.e. passengers, as well as system operator and society as a whole.

The overall procedure should lead to the proposal of the observed aspects of different entities: users, operators, the public, assessment of waiting time, operating costs and pollution reduction.

\section{Conclusion}


In modern cities, individual transport leads to serious problems related to: congestion on roads and environmental pollution. It is extremely important to strive to change people's travel behavior towards the use of more sustainable means of transport like as public passenger transport. It can be achieved by using the concept of to create a proposal of procedure for implementation of the integrated transport system. The aim is to support the city inhabitants to use public means of transport. The experience gained abroad show the importance of integrated transport. Reduction of transport serviceability has caused the transfer of travelers to individual transport. The transport integration is not a simple process as indicated in this article. However, it is important to overcome the greatest barrier of integration - the lack of funds in public resources. Poliak at all [15] deal with the ways of obtaining financial resources.

\section{Acknowledgements}

This work was supported by the Slovak Research and Development Agency under the contract No. SK-PL-2015-0019 and VEGA no. 1/0143/17 POLIAK, M.: Increasing the competitiveness of Slovak carriers providing road transport services in the common market of the European Union.

\section{References}

[1] Poliak, M. (2013). Relationship of reasonable profit and risk in public passenger transport in the Slovak Republic (in Slovak). Ekonomicky casopis/Journal of Economics, 61(2), 206-220. ISSN 0013-3035.

[2] Hine, J. (2000). Integration integration integration... Planning for sustainable and integrated transport systems in the new millennium. Transport Policy, 7(3), 175-177. DOI: 10.1016/S0967-070X(00)00025-1.

[3] Hull, A. (2005). Integrated transport planning in the UK: from concept to reality. Journal of Transport Geography, 13(4), 318-328. ISSN 0966-6923.

[4] Ibrahim, M.F. (2003). Improvements and integration of a public transport system: The case of Singapore. Cities, 20(3), 205-216. DOI: 10.1016/S0264-2751(03)00014-3.

[5] Dydkowski, G. (2005). Integration of local public transport (in Polish). Zeszyty Naukowe Politechniki Śląskiej. Transport, 60, 107-116.

[6] Preston, J. (2010). What's so funny about peace, love and transport integration? Research in Transportation Economics, 29(1), 329-338. ISSN 0739-8859. 
[7] Nosal, K. \& Solecka, K. (2014). Application of AHP method for multi-criteria evaluation of variants of the integration of urban public transport. Transportation Research Procedia, 3, 269278. DOI: $10.1016 /$ j.trpro.2014.10.006.

[8] May, A.D., Karlstrom, A., Marler, N., Matthews, B., Minken, H., Monzon, A., Page, M., Pfaffenbichler, P. \& Shepherd, S. (2005). Developing Sustainable Urban Land Use and Transport Strategies. In: A Decision Makers' Guidebook, second ed. Institute for Transport Studies, Leeds.

[9] Jones, P.M. (1998). Urban road pricing: public acceptability and barriers to implementation. In: Button, K.J., Verhoef, E.T. (Eds.), Road Pricing, Traffic Congestion and the Environment. Edward Elgar, Cheltenham.

[10] Melichar, V. \& Ježek, J. (2009). Effects of intake and ownership of cars on demand for public transport. Ekonomicko-technická revue Doprava 51(6), p. 22-30.

[11] Železný, R. (2007). The preference of public transport is an important dungeon of healthy urban development. In Od Koněspřežné železnice k vysokorychlostním dopravním systémům, 2007 (pp. 287-292). ČVUT, Prague, Czech Republic.

[12] European Commission. (2015). Transport. Facts \& findings Statistics. Retrieved August 12, 2016, from http://ec.europa.eu/transport/facts-fundings/statistics/pocketbook-2015_en.htm.

[13] Nedeliakova, E., Sekulova, J., Nedeliak, I. \& Abrahamovic, B. (2016). Application of Raymond Fisk model in research of service quality. Komunikacie, 18(2), 11-14, ISSN 1335 4205.

[14] Rodrigues, F.A.H. \& Santos, M.P.S. (1995). Scenario generation through cross-impact analysis: a literature review applied to the evaluation of transport alternatives: a literature review applied to the evaluation of transport alternatives. In Anais do IX ANPET - Congresso de Pesquisa e Ensino em Transportes, Vol. 2, 1995 (pp. 442-454). São Carlos.

[15] Poliak, M., Semanova, S. \& Varjan, P. (2016). The effectiveness of supporting public passenger transport from public funds. Transport and communications: scientific journal, 1, 10-16. ISSN 1339-5130. 